\title{
Fatostatin in Combination with Tamoxifen Induces Synergistic Inhibition in ER-Positive Breast Cancer [Corrigendum]
}

Liu Y, Zhang N, Zhang H, et al. Drug Des Devel Ther. 2020;14:3535-3545.

The authors have advised due to an error at the time of figure assembly, Figure 7C on page 3543 is incorrect. The correct Figure 7 is as follows.
The authors apologize for this error and advise it does not affect the results of the paper.
A

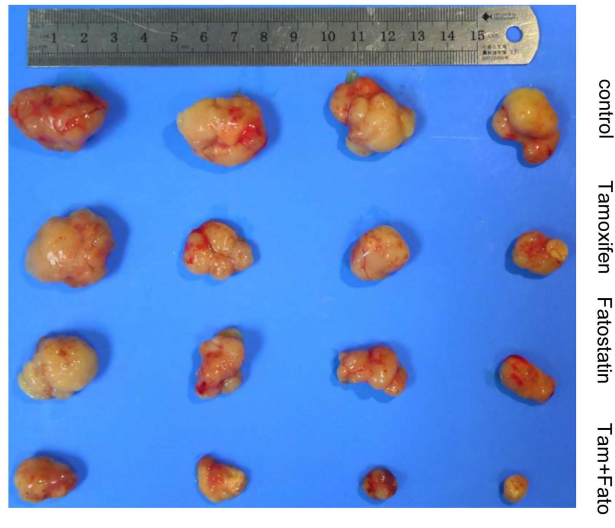

C

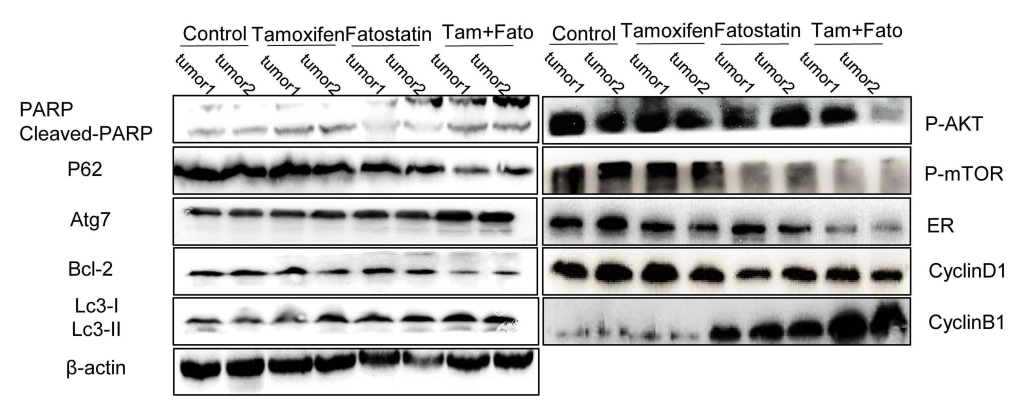

B

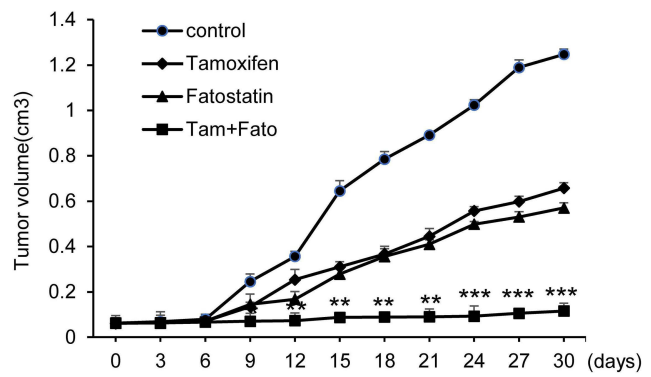

D

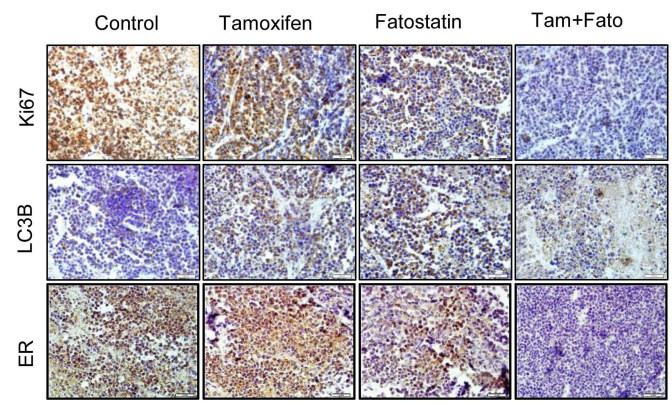

Figure 7 Effects of fatostatin and tamoxifen on the growth of ER-positive breast cancer in vivo. (A) Images of the xenograft tumours in nude mice implanted with MCF-7 cells $\left(|\times| 0^{7}\right)$ and treated with PBS, tamoxifen, fatostatin or a combination of tamoxifen and fatostatin $(n=4$ in each group). (B) Tumour growth curves of each treated group. The tumour volumes were assessed on the indicated days. (C) Western blot assay showing the protein expression levels of cleaved PARP, P62, Atg7, Bcl-2, LC3B, p-AKT, p-mTOR, ER, Cyclin DI and Cyclin BI among each group. (D) IHC analysis of Ki67, LC3B and ER expression in breast cancer at 20x magnification. Scale bars: $20 \mu \mathrm{m}$. The data are representative of independent experiments (means $\pm S D$ ) using one-way analysis of variance (ANOVA) to analyze the differences among groups. ${ }^{p} p<0.05 ; * * p<$ $0.01 ; * * * p<0.001$ vs the control group. 


\section{Publish your work in this journal}

Drug Design, Development and Therapy is an international, peerreviewed open-access journal that spans the spectrum of drug design and development through to clinical applications. Clinical outcomes, patient safety, and programs for the development and effective, safe, and sustained use of medicines are a feature of the journal, which has also been accepted for indexing on PubMed Central. The manuscript management system is completely online and includes a very quick and fair peer-review system, which is all easy to use. Visit http://www. dovepress.com/testimonials.php to read real quotes from published authors.

Submit your manuscript here: https://www.dovepress.com/drug-design-development-and-therapy-journal 